\title{
Recent progress on molecular breeding of rice in China
}

\author{
Yuchun Rao $\cdot$ Yuanyuan Li $\cdot$ Qian Qian
}

Received: 22 November 2013/Revised: 9 December 2013/Accepted: 10 December 2013/Published online: 19 January 2014 (C) The Author(s) 2014. This article is published with open access at Springerlink.com

\begin{abstract}
Molecular breeding of rice for high yield, superior grain quality, and strong environmental adaptability is crucial for feeding the world's rapidly growing population. The increasingly cloned quantitative trait loci and genes, genome variations, and haplotype blocks related to agronomically important traits in rice have provided a solid foundation for direct selection and molecular breeding, and a number of genes have been successfully introgressed into mega varieties of rice. Here we summarize China's great achievements in molecular breeding of rice in the following five traits: high yield, biotic stress resistance, abiotic stress resistance, quality and physiology. Further, the prospect of rice breeding by molecular design is discussed.
\end{abstract}

Keywords Molecular breeding - Marker-assisted selection · Breeding design - Agronomic traits · Rice breeding

\section{Introduction}

Rice is one of the most important staple crops in the world and serves as a model for monocots. In rice breeding, two breakthroughs have been made in China over the last

Communicated by N. Stewart.

Y. Rao · Y. Li · Q. Qian $(\bowtie)$

State Key Laboratory of Rice Biology, China National Rice

Research Institute, Hangzhou 310006, China

e-mail: qianqian188@hotmail.com

Y. Rao

College of Chemistry and Life Sciences, Zhejiang Normal

University, Jinhua 321004, China century. The first breakthrough is the development of a semi-dwarf rice variety in the 1960 s, which raised rice yield by more than $20 \%$ per unit area; the second breakthrough is the development of a hybrid rice variety with the three-line or cytoplasmic male sterile system in the 1970s, which led to another great increase in average rice yield by $20 \%$ (Yuan 1987). The previous achievements have contributed greatly to the self-sufficiency in China's food supply. Thereafter, however, no substantial progress has been made in improving rice yield. In 1986 and 1996, International Rice Research Institute and China launched the Super Rice Breeding Program to fight in stages for increasing rice yield. Recently, rapid economic development and population growth have placed heavy pressure on crop production in China. To meet the security of food supply, we must increase the crop yield per unit area by $50 \%$ before 2030 (Cheng and $\mathrm{Hu}$ 2008). In this context, it is imperative to find new applicable methods for rice breeding.

Conventional breeding selects genotypes indirectly through phenotypes, which is generally effective for qualitative traits only but not for quantitative traits. It is due to that quantitative traits with continuous variations are controlled by multiple genes and environmental factors. Over the past few decades, advances of molecular markers, transgenic technology, and genomics have exerted farreaching influences on the concept and means of conventional rice breeding, allowing applications of molecular breeding technology in rice. Molecular breeding refers to the development of new rice varieties by integrating the means of modern biotechnology into conventional breeding methods (Fig. 1), which mainly involve marker-assisted selection (MAS) and genetic engineering breeding (GEB).

Compensating the deficiencies of conventional breeding, molecular markers designed for direct genotypic identification are unrestricted to the ontogenetic periods of plants 
Fig. 1 The scheme of applying MDB to breed new varieties

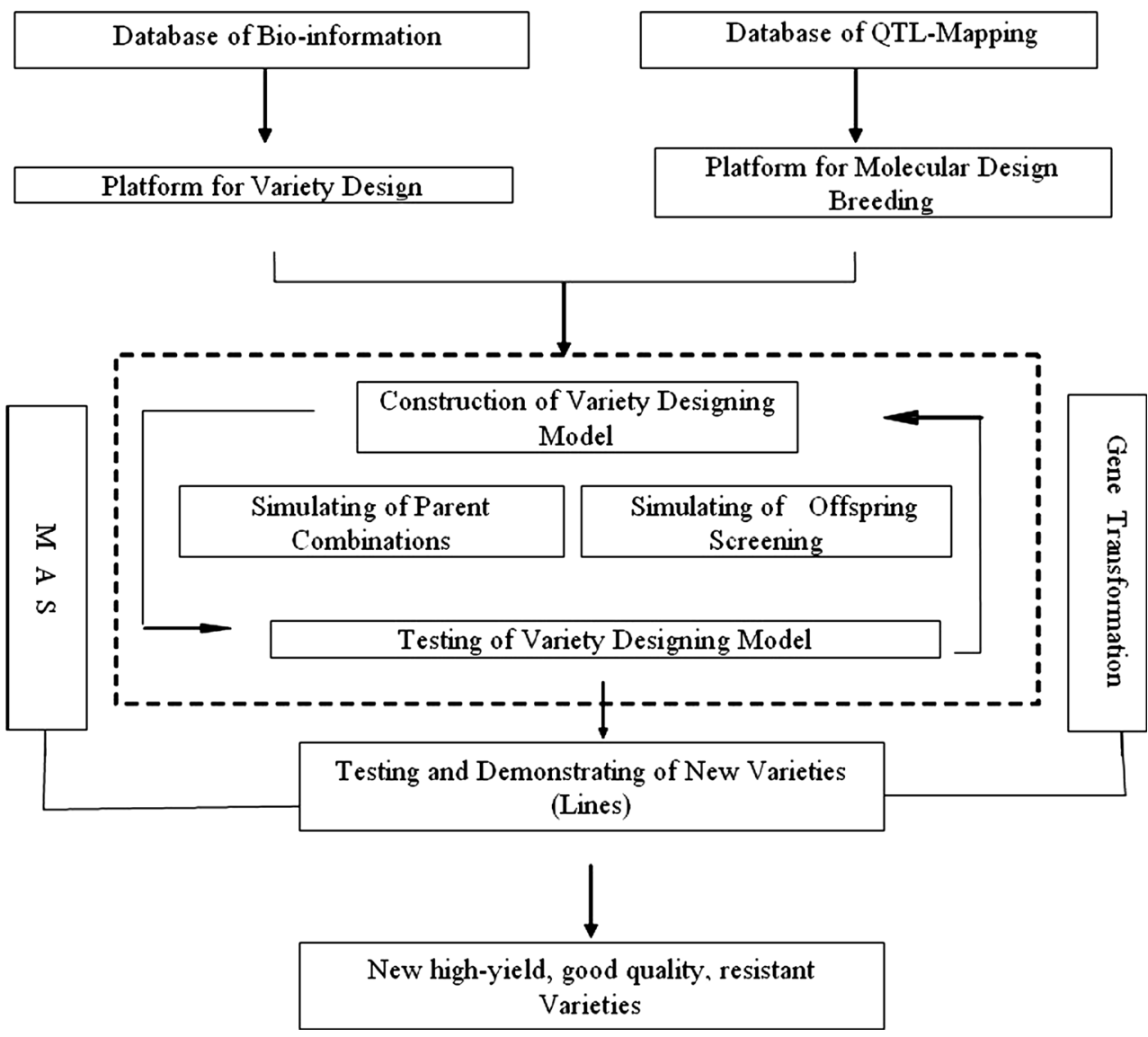

and can be used to select target traits directly. MAS involves four steps: overall program design, selection of target genes and parental materials, construction of breeding populations, and molecular marker screening of early generation materials. The breeding process of MAS is similar to that of conventional breeding, except that in the former method, molecular marker detection is involved in every breeding generation on the basis of conventional phenotypic identification.

GEB of rice mainly involves in vitro recombination of a specific target gene with the transformation vector, followed by transferring into rice for stable integration, expression, and heredity. This breeding method avoids the impacts of adverse genes caused by genetic linkage in the process of sexual hybridization and gets rid of reproductive isolation between different rice cultivars. Therefore, GEB provides an efficient way for cultivating new rice varieties.

In recent years, great efforts have been made in rice genome sequencing and there have been significant developments of functional genomics. The increasingly cloned quantitative trait loci (QTL)/genes, genome variations, and haplotype blocks related to agronomically important traits in rice provide a solid foundation for direct selection and molecular breeding of rice. A number of genes are successfully transferred into mega rice varieties.
Multiple chromosome segment substitution lines are constructed, and a large number of QTLs are identified. Many breeds carrying objective QTLs or genes are applied in rice production (Table 1), and an increasing number of rice varieties and genetic populations are sequenced, laying a foundation for rice breeding by molecular design. Here we summarize China's current situation of molecular breeding in rice regarding different traits, and further discuss the prospects of rice breeding by molecular design (MDB).

\section{Molecular breeding for high yield}

High yield is the eternal theme pursued by rice breeders. Super rice breeding in the model of ideal plant architecture using molecular design is the mainstream of future development in this field. Yield-related traits in rice include plant height, tiller number, grain weight, and panicle type. Of these, plant height is the most important trait related to plant architecture and linearly correlates with biomass. Panicle number, which consists of planting density and effective tiller number, is a major influencing factor of the total grain production per unit area. Panicle characters are directly linked with the yield of rice (Xing and Zhang 2010). Recently, multiple yield-related genes and QTLs 
Table 1 Examples of marker-assisted selection (MAS) and genetic engineering breeding (GEB) in rice

\begin{tabular}{|c|c|c|c|c|c|c|}
\hline Varieties/lines & Types & Genes involved & Donors & $\begin{array}{l}\text { Tolerance to/ } \\
\text { exploited traits }\end{array}$ & $\begin{array}{l}\text { Breeding } \\
\text { methods }\end{array}$ & Code/reference \\
\hline Zhonghui 8006 & Indica & Хa21, GM6 & Duoxi 1, Minghui 63 & $\mathrm{BB}, \mathrm{GM}$ & MAS & CNA20030473.9 \\
\hline Zhonghui 218 & Indica & $X a 21$ & IRBB 21 & BB & MAS & CNA20030093.8 \\
\hline Guodao 1 & Indica & $X a 21$ & Zhonghui 8006 & BB & MAS & CNA20050721.4 \\
\hline Guodao 3 & Indica & $X a 21$ & Zhonghui 8007 & BB & MAS & Cao et al. (2006) \\
\hline Guodao 6 & Indica & $X a 21$ & Zhonghui 8008 & BB & MAS & CNA20050722.2 \\
\hline IIYou 8006 & Indica & $X a 21$ & Zhonghui 8006 & BB & MAS & Wu et al. (2008c) \\
\hline IIYou-218 & Indica & $X a 21$ & Zhonghui 218 & BB & MAS & CNA20060721.9 \\
\hline Yuanhui 611 & Indica & yld 1.1, yld 2.1 & O. rufipogon & High yield & MAS & CNA20030432.1 \\
\hline Y-You 7 & Indica & yld1.1, yld 2.1 & Yuanhui 611 & High yield & MAS & Wu et al. (2010a) \\
\hline RB207-1 & Restorer & \multicolumn{2}{|c|}{ Barnyardgrass Genomic DNA } & High yield & GEB & CNA20030177.2 \\
\hline Shuhui 527 & Restorer & $\mathrm{Xa4}, \mathrm{Xa21}$ & 1318/88-R3360 & BB & MAS & CNA20000073.X \\
\hline Zhunliangyou 527 & Indica & $\mathrm{Xa4}, \mathrm{Xa21}$ & Shuhui 527 & BB & MAS & CNA20030033.4 \\
\hline D-You 527 & Indica & $X a 4, X a 21$ & Shuhui 527 & $\mathrm{BB}$ & MAS & CNA20010111.0 \\
\hline Xieyou 527 & Indica & $X a 4, X a 21$ & Shuhui 527 & BB & MAS & CNA20030434.8 \\
\hline RGD-7S/RGD-8S & $C M S$ & Pi1, Pi2 & BL122 & $\mathrm{RB}$ & MAS & Liu et al. (2008b); \\
\hline Yueza 746/763 & Indica & Pil, Pi2 & RGD-7S & $\mathrm{RB}$ & MAS & Jin et al. (2007) \\
\hline W3660 & Japonica & $\operatorname{Lgc-1}$ & LGC-1 & Low glutelin content & MAS & CNA20020113.1 \\
\hline W017 & Japonica & $\operatorname{Lox} 3$ & DawDam & Prolonged storage of seeds & MAS & CNA20020290.1 \\
\hline W025 & Japonica & $g e$ & Haiminori & Huge embryo & MAS & CNA20030548.4 \\
\hline Huahui 1 & Restorer & CrylAc/CrylAb & Minghui 63 & Insects & GEB & Liu et al. (2012) \\
\hline Zhonghui 161 & Restorer & Pita, $x a 13, w x$ & IRBB 51, Teqing & $\mathrm{RB}, \mathrm{BB}$, good quality & MAS & CNA20060673.5 \\
\hline Bph68S/Luohong4A & $C M S$ & Bph14, Bph15 & B5 & $\mathrm{BPH}$ & MAS & Zhu et al. (2013) \\
\hline Ning 9108 & Indica & $S t v-b i, W x-m q$ & Guandong 194 & Strip blight, good quality & MAS & Yao et al. (2010) \\
\hline T16S & $G M S$ & $B t$ & Minghui 63 & Insects & GEB & Wu et al. (2010b) \\
\hline
\end{tabular}

$\mathrm{BB}$, bacterial blight; RB, rice blast; GM, gall midge; $\mathrm{BPH}$, blight planthopper; Bt, Bacillus thuringiensis; MAS, marker-assisted selection breeding; GEB, genetic engineering breeding

have been identified and cloned in rice (Table 2), providing a good opportunity for molecular breeding with greater potential of rice yield.

In 1991, the high-stem gene eui was first transferred into the widely used sterile line Zhenshan 97A by MAS. In the following year, this gene was transferred into other sterile lines using the backcrossing method to overcome the issue of elongated internodes of sterile lines (Liang et al. 1992). Recently, the dense and erect panicle 1 (DEP 1) gene, closely related to plant type, has been cloned (Huang et al. 2009). Using an elite indica variety (curved panicle type Nanhui 602) as female parent and a NIL-DEPl DW135 as male parent, researchers carried out MAS of backcross population, screened out a DEP1-containing homozygous line, and further investigated panicle traits in heading date; the results were consistent with molecular marker detection data, providing a theoretical reference and materials for future plant architecture breeding (Cheng et al. 2011).

Yang et al. (2010) and Wang et al. (2012b) effectively improved the grain size and the exterior quality of an indica variety, Huajingxian 74 , by molecular pyramiding breeding, which involved the hybridization of a single segment substitution line that has genetic background of Huajingxian 74 and carries the grain length genes $G S 3$ and GW8 with other excellent genes. Recently, the characteristics of panicle size have been improved significantly by clustering 8 panicle number and weight-related QTLs via MAS (Zong et al. 2012). Meanwhile, the strong restorer line Q611 and the hybrid rice variety Y-You-7 were obtained by transferring two high-yield genes of the Malaysian wild rice Oryza rufipogon, yld1.1 and yld2.1 (Wu et al. 2010a), into the elite restorer lines Ce64-7 and 9311 via MAS (Table 1 ).

In 2003, the State Key Laboratory of Rice Biology (SKLRB) of China National Rice Research Institute (CNRRI) cooperated with the research group of Academician Li Jiayang from Chinese Academy of Sciences to complete the cloning of rice monoculm 1 (MOCl) gene ( $\mathrm{Li}$ et al. 2003). With the help of MOCl cloning, the SKLRB of CNRRI launched a research project funded by the 863 program, Creation and Applications of Super High-yielding Germplasm of MOCl Transgenic Rice. This project mainly aimed to transfer sense, antisense, and deletion genes of $\mathrm{MOCl}$ into mega variety and the parents of hybrid 
Table 2 Map-based cloning of genes using mutants or QTL as a tool involved in rice high yield in recent years

\begin{tabular}{|c|c|c|c|c|c|}
\hline Trait & $\begin{array}{l}\text { QTL or } \\
\text { mutant }\end{array}$ & QTL/gene & RAP-DB & Encoded product & Reference \\
\hline \multirow[t]{8}{*}{ Plant architecture } & mutant & HTD2 & Os03g0203200 & Putative esterase & Liu et al. (2009) \\
\hline & mutant & OsCD1 & Os $12 \mathrm{~g} 0555600$ & Cellulose synthase & Luan et al. (2011) \\
\hline & mutant & OsGA2ox6 & Os04g0522500 & Gibberellin 2-oxidase & Huang et al. (2010) \\
\hline & QTL & $I P A 1 / W F P$ & Os08g0509600 & Squamosa promoter binding protein-like 14 & Jiao et al. (2010) \\
\hline & QTL & OsPH1 & Os01g0881500 & Chitin-inducible gibberellin-responsive protein & Kovi et al. (2011) \\
\hline & mutant & $L A Z Y 1$ & Os11g0490600 & Expressed protein & Li et al. (2007) \\
\hline & mutant & PROG1 & Os07g0153600 & Cys2-His2 zinc finger protein & Jin et al. (2008) \\
\hline & mutant & $D L T$ & Os06g0127800 & GRAS family protein (involved in brassinosteroid) & Tong et al. (2012) \\
\hline \multirow[t]{12}{*}{ Panicle characters } & mutant & EUI1 & Os05g0482400 & Cytochrome P450 monooxygenase & Zhang et al. (2008) \\
\hline & mutant & suil & Os01g0118300 & Phosphatidyl serine synthase & Zhu et al. (2011) \\
\hline & mutant & $S P 1$ & Os11g0235200 & Peptide transporter & Li et al. (2009b) \\
\hline & mutant & $L A X 2$ & Os04g0396500 & Nuclear protein with a plant-specific conserved domain & Hiroaki et al. (2011) \\
\hline & QTL & Ghd7 & Os07g0261200 & $\mathrm{CCT}$-domain protein & Xue et al. (2008) \\
\hline & mutant & DEP2/SRS1 & Os07g0616000 & Novel plant-specific protein & Li et al. (2010a) \\
\hline & mutant & $L A Z Y 1$ & Os11g0490600 & Specific herb protein & Chen et al. (2012) \\
\hline & mutant & EG1 & Os01g0900400 & Lipase & Li et al. (2009a) \\
\hline & QTL & DTH8/Ghd8 & Os08g0174500 & OsHAP3 subunit of a CCAAT-box-binding protein & Wei et al. (2010) \\
\hline & QTL & $\begin{array}{l}D E P 1 / q P E 9- \\
1\end{array}$ & Os09g0441900 & PEBP-like domain protein & Huang et al. (2009) \\
\hline & mutant & $D E P 3$ & Os06g0677000 & Patatin-like phospholipase A2 protein & Qiao et al. (2011) \\
\hline & mutant & OsPIN2 & Os06g0660200 & Auxin efflux transporter & Chen et al. (2012) \\
\hline \multirow[t]{6}{*}{ Grain } & QTL & GS3 & Os03g0407400 & Transmembrane protein & Yang et al. (2010) \\
\hline & QTL & Gnla & Os01g0197700 & Cytokinin oxidase/dehydrogenase & Li et al. (2013) \\
\hline & QTL & GS5 & Os05g0158500 & Serine carboxypeptidase & Li et al. (2011b) \\
\hline & QTL & $G W 2$ & Os02g0244100 & RING-type E3 ubiquitin ligase & Song et al. (2007) \\
\hline & QTL & GW5 & Os05g0187500 & Novel nuclear protein & Weng et al. (2008) \\
\hline & QTL & $G W 8$ & Os08g0531600 & Squamosa promoter binding protein-like 16 & Wang et al. (2012b) \\
\hline \multirow[t]{2}{*}{ Tiller } & mutant & $M O C 1$ & Os06g0610350 & GRAS family nuclear protein & Li et al. (2003) \\
\hline & QTL & $T A C 1$ & Os09g0529300 & Unknown & Jiang et al. (2012) \\
\hline $\begin{array}{l}\text { Heading and } \\
\text { grain weight }\end{array}$ & mutant & $H G W$ & Os06g0160400 & Ubiquitin-associated domain protein & Li et al. (2012b) \\
\hline Grain filling & QTL & GIF1 & Os04g0413500 & Cell wall invertase & Wang et al. (2010a) \\
\hline Shattering & QTL & SHA1 & Os04g0670900 & Plant-specific transcription factor & Lin et al. (2007) \\
\hline
\end{tabular}

rice for changing MOCl expression level and regulating rice tiller numbers.

In addition, GEB has been applied for screening transgenic plants with less or no tillers, good agronomic traits, and great potential for high yield. To date, more than 50 transgenic lines have been bred using the pedigree methods and 30 transgenic intermediate materials are obtained. Of these, three transgenic varieties were further selected for significantly improved production and potential for application compared to the control lines; four lines with fewer tillers were used for variety demonstration; and some lines were used as intermediate materials. In addition, MOCI transgenic pure lines were hybridized with conventional varieties such as Zhi-7 and Zhongchao-123, and a series of
MOC1-containing breeding materials from different generations were obtained by transformation, including 40 intermediate materials from advanced lines.

Previous work indicates that using modern genetic engineering technology, we are able to obtain transgenic plants with fewer tillers, high nutrient contents, and superior agronomic traits in super rice breeding. The gradient tiller materials generated by transgenosis are expected to provide a new platform for exploring the theory and technology of super rice breeding. With the cloning of IPA1, great breakthroughs have been made in understanding the mechanism of ideal plant architecture in rice. It has been reported that IPAI contributes mostly to more panicles, strong culms, and high-yield potential. This gene 
has been transferred into the rice cultivar Xiushui 11 through backcross breeding and the obtained mutant lines exhibit ideal plant architecture with a $10 \%$ increase in the yield in field experiments (Jiao et al. 2010).

In overseas, great achievements also had been acquired. Previously, the plant height gene $s d l$ was transferred from the variety Habataki into the variety Koshihikari using MAS; near-isogenic lines NIL-GNl + sdl, a kind of semidwarf, large-panicle, high-yielding lines, were constructed (Ashikari et al. 2005), providing a new pathway for the green revolution in rice.

\section{Molecular breeding for resistance to biotic stress}

In rice production, biotic stress mainly refers to plant diseases and pests. The major rice diseases are fungal, bacterial, and viral diseases and rice blast. Serious losses to rice production are commonly caused by more than 70 diseases, of which rice blast, sheath blight, and bacterial blight are most harmful to rice. In addition, rice is one of the crops suffering from most pests' attacks. There are more than 624 insect species in field harmful to rice, of which planthopper, leafhopper, and stemborer cause the most serious hazards and lead up to $32 \%$ yield losses in rice (Pei et al. 2011). Controlling of the pests and breeding of disease-resistant varieties have long been the focus of rice research. In China, a number of exploratory studies have been conducted on plant disease resistance in rice, and a series of relevant genes (e.g., Xa21) have been cloned and applied in rice production (Table 3 ). These works have greatly promoted rice breeding for high resistance to biotic stress by MAS and GEB.

Bacterial blight and rice blast resistance genes are most commonly used in rice breeding for disease resistance. Since the bacterial blight-resistant gene $\mathrm{Xa21}$ is tightly linked to the molecular marker PTA248, researchers from CNRRI detected homozygous-resistant plants using the molecular marker in the offspring of a cross of Xa21containing variety IRBB21 and non-Xa21-containing variety IR24; two Xa21-carrying restorer lines, Zhonghui 8006 and Zhonghui 218 (Table 1), were bred, and a series of super rice combinations were obtained, such as Guodao 1 (Cao et al. 2005), Guodao 3 (Cao et al. 2006), Guodao 6 (Wu et al. 2008b), and II You 8006 (Wu et al. 2008c). In addition, maintainer lines pyramiding three rice blast resistance genes (Pi-1,Pi-2, and $P i-33)$ and maintainer and restorer lines pyramiding a rice blast resistance gene $(P i$ $25)$ with two bacterial blight resistance genes (Xa-23 and $X a-21)$ were created. With the help of MAS, new resistance rice lines pyramiding multiple bacterial blight resistance genes $(\mathrm{Xa} 4, \mathrm{Xa13}$, and $\mathrm{Xa21})$ were screened out from the offspring of a cross between the variety IBRR60 and multiple disease-resistant varieties (Deng et al. 2005). In recent years, these rice varieties have been applied in rice production in an average annual area of approximately $35,000 \mathrm{hm}^{2}$, which are considered to be successful examples for commercial application of bacterial blight resistance genes.

Using MAS, Wang et al. (2004b) transferred two bacterial blight resistance genes, $\mathrm{Xa} 21$ and $\mathrm{Xa} 4$, into restorer lines, bred the disease-resistant, high-affinity restorer line Shuhui 527, and configured a combination of two-line hybrid rice Zhunliangyou 527 and three-line hybrid rice D You 527, Gangyou 527, and Xieyou 527 (Table 1). In addition, Liu et al. (2008b) and Jin et al. (2007) transferred $X a 7$ into three-line restorer lines and bred the restorer lines Guanghui 806 and Guanghui 312. Pi-1 and Pi-2 were also, respectively, transferred into the sterile lines GD-7S and GD-8S for breeding the new sterile lines RGD-7S and RGD-8S (Table 1) for high resistance to rice blast, and new combinations of two-line hybrid rice with high resistance to rice blast were screened out, including Yueza 746, Yueza 751, Yueza 4206, and Yueza 750.

On the other hand, gene loci were detected in segregating generations of Wuyunjing 8 and Zhendao 42 using gene markers of $P i-t a$ and $P i-b$ and molecular markers tightly linked with $S t v-b i$; the three disease resistance genes were transferred simultaneously into high-yield varieties to breed a high-yield, good-quality, and multi-resistance new rice line, 74121 , by a combination of multi-generation breeding in field with resistant gene identification (Wang et al. 2011). In another study, the rice blast resistance gene $\mathrm{Pi}-\mathrm{l}$ was transferred into the three-line sterile line Jinkang A (Guan et al. 2009). Recently, continuous breakthroughs have been made in molecular breeding of rice for resistance to stripe diseases. Pyramiding breeding was carried out by configuring hybrid combinations between the Jiangsu high-yielding rice variety Wuyunjing 7 as female parent and the Japanese japonica variety Guandong 194 (containing the stripe disease resistance gene $S t v-b i$ and dark endosperm mutant gene $W x-m q$ ) as male parent to breed new disease-resistant rice lines with good cooking quality (Yao et al. 2010).

In rice molecular breeding for high resistance to pest, the elite two-line restorer line Yangdao 6 was hybridized with a selectable marker-eliminated $B t$ transgenic restorer line Minghui 63 to breed the transgenic pest-resistant photo-thermo-sensitive genic male sterile line T16S (Wu et al. 2010b). In 2013, the Honglian-type new sterile line Luohong 4A resistant to brown planthopper (BPH) was bred in Wuhan University by a combination of MAS and conventional breeding; Luohong 4A demonstrated significant BPH resistance by pyramiding two BPH-resistant genes, Bph14 and Bph15 (Zhu et al. 2013).

Xiao et al. (2005) transferred the rice gall midge (RGM)-resistant gene Gm6 into the restorer lines Gui99 
Table 3 Major important genes tagged and mapped with molecular markers in rice for biotic stresses in recent years

\begin{tabular}{|c|c|c|c|c|c|}
\hline Biotic stress & Gene & Donor & Chr. & Linked marker & Reference \\
\hline \multirow[t]{11}{*}{ Bacterial blight } & Xa13 & IRBB13 & 8 & R2027 (1.3 cM), RG136(2.3 cM) & Li et al. (2012a) \\
\hline & Xa4 & IRBB4 & 11 & R1506, s12886 (0.5 cM) & Deng et al. (2005) \\
\hline & $X a 7$ & IRBB7 & 6 & G1091 (6.0 cM), AFLP31-10 (3 cM) & Porter et al. (2003) \\
\hline & $X a 21$ & O. longistaminata & 11 & RG103 (0 cM) & Gan et al. (2011) \\
\hline & $X a 22(t)$ & Zhachanglong & 11 & RG103 (0 cM) & Pei et al. (2011) \\
\hline & $X a 23$ & O. rufipogon & 11 & C1003A (0.4 cM) & Chen et al. (2009) \\
\hline & $x a 24$ & DV85, DV8, Aus 295 & 2 & RM14222 (0.07 cM), RM14226 (0.07 cM) & Wu et al. (2008d) \\
\hline & $X a 25(t)$ & Minghui63 & 12 & G1314 (7.3 cM), R887 & Pei et al. (2011) \\
\hline & Xa29 & O. officinalis & 1 & C904, R596 & Tan et al. (2004) \\
\hline & $x a 32(t)$ & Y76 & 12 & RM8216 (6.9 cM)-RM20A (1.7 cM) & Ruan et al. (2008) \\
\hline & $x a 34(t)$ & BG1222 & 1 & RM10929, BGID25 & Chen et al. (2011b) \\
\hline \multirow[t]{8}{*}{ Rice blast } & Pil & LAC23 & 11 & RZ536 (7.9 cM), Npb181 $(3.5 \mathrm{cM})$ & Hua et al. (2012) \\
\hline & Pi2/Pi9 & 5173 & 6 & RG64 (0.9 cM), AP22 (1.2 cM) & Zhu et al. (2012) \\
\hline & $\operatorname{Pi9}(t)$ & Oryza minuta & 6 & $\mathrm{~Pb} 9-1$ & Chen et al. (2009) \\
\hline & Pid3/Pi25 & Gumei2 & 6 & A7 $(1.7 \mathrm{cM}), \mathrm{RG} 456(1.5 \mathrm{cM})$ & Chen et al. (2011a) \\
\hline & Pi33 & IR64 & 8 & Y2643L (0.9 cM), RM72 $(0.7 \mathrm{cM})$ & Miah et al. (2013) \\
\hline & Pik-p & K60 & 11 & RM5926-K37 & Yuan et al. (2011) \\
\hline & Pi41 & Nov-93 & 12 & STS40-1-STS40-3 & Yang et al. (2009b) \\
\hline & $\operatorname{Pid}(t)$ & Digu & 2 & G1314A (1.2 cM), G45 (10.6 cM) & Pei et al. (2011) \\
\hline \multirow[t]{3}{*}{ Brown planthopper } & Bph6 & Swarnalata & 11 & RM6997-RM5742 & Qiu et al. (2010) \\
\hline & Bph14 & O. officinalis & 3 & G1318-R1925 & Zhu et al. (2013) \\
\hline & $B p h 19(t)$ & AS20- 1 & 3 & RM6308-RM3134 & Chen et al. (2006) \\
\hline $\begin{array}{l}\text { White-backed } \\
\text { planthopper }\end{array}$ & $\operatorname{Wbph} 6(t)$ & Guiyigu & 11 & RM167-RM287 & Li et al. $(2010 a, b)$ \\
\hline Gall midge & GM6 & Duokang1 & 4 & PSM101, PSM106, PSM115 & Xiao et al. (2005) \\
\hline Stripe disease & $s t v-b i$ & & 11 & ST10 & Yao et al. (2010) \\
\hline Insects & $B t$ & Bacillus thuringiensis & & & Chen et al. (2009) \\
\hline
\end{tabular}

and Guanghui 998 using the gene marker PSM101 and preliminarily bred the RGM-resistant restorer lines KG18-1 and KG18-2. In September 2009, the Ministry of Agriculture issued a security certificate to the crylAb/crylAc transgenic insect-resistant rice Huahui 1 and $B t$ Shanyou 63 for production permissions in Hubei Province (Liu et al. 2012). Scientists from Science Academy of China created new-type pest-resistant transgenic materials and carried out bio-safety evaluations for non-selectable marker sck/ crylAc double gene insect-resistant transgenic rice lines, derived varieties, and their hybrid combinations. Zhang et al. (2013b) created three copies of new restorer materials containing the major QTLs, qSI4, of anti-feeding resistance to white-backed planthopper by a combination of MAS and conventional breeding.

For cultivating new rice varieties resistant to both plant diseases and pests, multi-gene pyramiding breeding has been carried out. For example, genes highly resistant to bacterial blight $(\mathrm{Xa23})$, rice blast (Pi9), and rice stem borer and leaf roller $(\mathrm{Bt})$ were pyramided into the same lines using MAS to obtain a pure line with comparable resistance to specific biotic stresses mentioned above (Chen et al. 2009). In addition, two anti-aging genes (IPT and Xa23) and a rice blast resistance gene $(P i b)$ were pyramided into the same lines to obtain anti-aging, bacterial blight-resistant, and rice blast-resistant intermediate materials for crossbreeding (He et al. 2004).

\section{Molecular breeding for resistance to abiotic stress}

Abiotic stress of rice is collectively referred to natural adversity and artificial adversity. Natural adversity includes meteorological disasters (e.g., floods, droughts, typhoons, and cold damage) and soil adversity (e.g., salt damage); artificial adversity is mainly human-induced environmental pollution. In recent years, molecular breeding for abiotic stress tolerance in rice has been developed significantly, and a series of genes and QTLs have been identified for their high application potential in rice breeding for resistance to adversity (Table 4). 
Table 4 Major important genes tagged and mapped with molecular markers in rice for abiotic stress, quality, physiology and hybrid traits in recent years

\begin{tabular}{|c|c|c|c|c|c|}
\hline Trait & Gene & RAP-DB & Encoded product & Gene function & Reference \\
\hline \multirow{11}{*}{$\begin{array}{l}\text { Abiotic } \\
\text { resistance }\end{array}$} & OsTPPI & Os02g0661100 & Trehalose-6-phosphate phosphatase & Tolerance to salt and cold & Ge et al. (2008) \\
\hline & OCPII & Os01g0615100 & Chymotrypsin inhibitor & Tolerance to drought & Huang et al. (2007) \\
\hline & LTN1 & Os05g0557700 & $\begin{array}{l}\text { Ubiquitin-conjugating domain } \\
\text { protein }\end{array}$ & Signal of Pi starvation & Hu et al. (2011) \\
\hline & OsLEA3-1 & Os05g0542500 & $\begin{array}{l}\text { Late embryogenesis abundant } \\
\text { protein }\end{array}$ & Tolerance to drought & Xiao et al. (2007) \\
\hline & OsPhtl & Os10g0444700 & Phosphate transporter & Absorption and transport of $\mathrm{Pi}$ & Jia et al. (2011) \\
\hline & OsSKIPa & Os02g0759800 & Unknown & Tolerance to drought & Hou et al. (2009) \\
\hline & LOX3 & Os03g0700400 & Lipoxygenase & Tolerance to various stress & Liu et al. (2008a) \\
\hline & OsCOIN & Os01g0104100 & Zinc finger protein & Tolerance to salt, cold and drought & Liu et al. (2007b) \\
\hline & OsHAL3 & Os06g0199500 & Halotolerance protein & Tolerance to salt & Sun et al. (2009) \\
\hline & SKC1 & Os01g0307500 & $\mathrm{Na}^{+}$-selective transporter & Tolerance to salt & Ren et al. (2005) \\
\hline & $S N A C 2$ & Os01g0884300 & Nuclear protein & Tolerance to salt and cold & Hu et al. (2008) \\
\hline \multirow[t]{6}{*}{ Quality } & OsVPE1 & Os04g0537900 & Vacuolar processing enzyme & Maturity of gluten & Wang et al. (2009b) \\
\hline & RSRl & Os05g0121600 & Unknown & Regulating starch synthesis of seeds & Fu and Xue (2010) \\
\hline & OsRab5a & Os12g0631100 & Small GTPase & Transporting storage protein & Wang et al. (2010b) \\
\hline & $A L K$ & Os06g0229800 & Soluble starch synthases & Regulating gel temperature & Gao et al. (2003) \\
\hline & $q G C-6(w x)$ & Os06g0133000 & Granule-bound starch synthase & Regulating amylase content & Su et al. (2011) \\
\hline & $O s B A D H 2 / f g r$ & Os08g0424500 & Betaine aldehyde dehydrogenase & Fragrance & Chen et al. (2008) \\
\hline \multirow[t]{8}{*}{ Physiology } & Phrl & Os04g0624500 & Polyphenol oxidase & Browning seeds & Yu et al. (2008) \\
\hline & OsMST6 & Os07g0559700 & Monosaccharide transporter & Regulating grain filling & Wang et al. (2008) \\
\hline & $S L L 1$ & Os09g0395300 & KANADI Transcription Factor & Regulating leaf morphology & Zhang et al. (2009) \\
\hline & $L C 2$ & Os02g0152500 & Unknown & Regulating leaf angle and flowering & Wang et al. (2013) \\
\hline & $\operatorname{Roc} 5$ & Os02g0674800 & Leu-chain-like protein & Regulating leaf morphology & Zou et al. (2011) \\
\hline & $N L S 1$ & Os11g0249000 & $\begin{array}{l}\text { Typical CC-NB-LRR domain } \\
\text { protein }\end{array}$ & Resistance to pathogens & Tang et al. (2011) \\
\hline & $S L 1$ & Os01g0129200 & Z-finger domain protein & Regulating rice floral development & Xiao et al. (2009) \\
\hline & $\begin{array}{l}\text { NRLII } \\
\text { OsCSLD4 }\end{array}$ & Os12g0555600 & Cellulose synthase & Cell-wall synthesis and plant growth & Yoshikawa et al. (2013) \\
\hline \multirow[t]{21}{*}{ Physiology } & OsRAAl & Os01g0257300 & $12 \mathrm{kDa}$ small $\mathrm{G}$ protein & Regulating root growth & Han et al. (2008) \\
\hline & WOX11 & Os07g0684900 & Unknown & Regulating root growth & Zhao et al. (2009) \\
\hline & OsC6 & Os11g0582500 & Lipid transfer protein & Involving in anthers development & Zhang et al. (2010b) \\
\hline & OsPSS1 & Os04g0573000 & Pi-transport protein & Involving in Pi balance of leaves & Wang et al. (2012a) \\
\hline & PTCl & Os09g0449000 & PHD-Finger Protein & Involving in anthers development & Li et al. $(2011 \mathrm{a}, \mathrm{b})$ \\
\hline & OsJAG & Os01g0129200 & $\mathrm{C} 2 \mathrm{H} 2 \mathrm{Z}$-finger domain protein & Involving in floral development & Duan et al. (2010) \\
\hline & CYP704B2 & Os03g0168600 & Cytochrome P450 & Regulating anther and pollen formation & Li et al. (2010b) \\
\hline & OsMST4 & Os03g0218400 & Monosaccharide transporter & Regulating sugar distribution & Wang et al. (2007) \\
\hline & OsYABBY4 & Os02g0643200 & YABBY-domain protein & Expressing in vascular tissues & Liu et al. (2007a) \\
\hline & SDG714 & Os01g0927000 & Histone $\mathrm{H} 3 \mathrm{~K} 9$ methyl-transferase & Regulating leaf morphology & Ding et al. (2007a) \\
\hline & OsAGO7 & Os03g0449200 & Argonaute (AGO) protein & Regulating leaf morphology & Shi et al. (2007) \\
\hline & RID1 & Os10g0419200 & $\begin{array}{l}\text { Cys2/His2 type } z \text {-finger } \\
\text { transcription factor }\end{array}$ & Regulating reproductive growth & Wu et al. (2008a) \\
\hline & S5 & Os06g0213100 & Aspartic protease & Regulating reproductive isolation & Ji et al. (2012) \\
\hline & $S a$ & Os01g0578700 & $\begin{array}{l}\text { Small ubiquitin-like modifier E3 } \\
\text { ligase-like protein/F-box protein }\end{array}$ & Regulating male sterility & Long et al. (2008) \\
\hline & EUII & Os05g0482400 & $\begin{array}{l}\text { Cytochrome P450 monooxygenase } \\
\text { CYP714D1 }\end{array}$ & Hybrid rice pollination & Zhang et al. (2008) \\
\hline & OsUgpl & Os09g0553200 & UDP-glucose pyrophosphorylase & Male fertility & Chen et al. (2007) \\
\hline & $C S A$ & Os01g0274800 & $\begin{array}{l}\text { R2R3-type MYB transcription } \\
\text { factor }\end{array}$ & Mutation causing sensitive male sterility & Zhang et al. (2013a) \\
\hline & orfH79 & Mitochondria & Cytotoxic peptide & Regulating in HL-CMS & Peng et al. (2010) \\
\hline & COX11 & Os03g0718600 & $\begin{array}{l}\text { Nuclear-encoded mitochondrial } \\
\text { protein }\end{array}$ & Interacting with WA352 & Luo et al. (2013) \\
\hline & WA352 & Mitochondria & Unknown & Regulating in WA-CMS & \\
\hline & $R f 5 / R f 1$ & Os10g0497300 & PPR protein & Restoring fertility of BT-CMS & Hu et al. (2012) \\
\hline
\end{tabular}


Drought resistance is a complex trait in plants, which refers to the tolerance of plants to water-deficient environment. The existing technical evaluation and standards for drought resistance cannot reflect the actual growth conditions of plants accurately. In China, studies have been reported on QTL mapping of drought resistance traits in rice and number of relevant genes cloned (Table 4). Eight QTL for rice root traits were identified in the doubled haploid (DH) lines Zhaiyeqing 4 and Jingxi 17 (Xu et al. 2001), and two drought-tolerant QTL, qDT5 and qDT12, were detected at seedling stage and located at GA41GA257 on chromosome 5 and RG457-Y12817R on chromosome 12 (Teng et al. 2002). Drought-tolerant QTLs including root traits (diameter, length, weight, and root/ shoot ratio), leaf water potential and osmotic potential, as well as plant height, stem diameter, and flag leaf length and width were identified in $\mathrm{DH}$ lines of two japonica rice varieties, IRAT 109 and Yuefu, under different environmental conditions (root irrigation, potted paddy field, and dry land); in total, 21 additive QTL and 23 pairs of epistatic QTL were detected, and environmental interaction was detected in QTLs of root number, root fresh weight, root dry weight, and root/shoot ratio, but not in QTLs of basal root thickness, maximum root length, fresh stem weight, or dry stem weight; overall, the QTLs controlling fresh and dry root weights had the most significant interactions with the environment, accounting for 26 and $28 \%$ of the variance, respectively ( $\mathrm{Mu}$ et al. 2003). In addition, droughtrelated QTLs such as those associated with fresh root weight and leaf water potential were identified in different populations of recombination inbred lines (RILs) in paddy field and dry land (Qu et al. 2008). Knowledge of these QTLs will benefit MAS breeding of rice for drought resistance.

Cold damage of rice occurs at the budding, seedling, booting, flowering, and grain filling stages. Of these, anticold stress in the seedling stage is the focus of relevant research. QTLs related to cold stress have been identified with different methods (Table 4). Backcross generation was analyzed in 213 lines of Xieqingzao B and Dongxiang wild rice with the seedling mortality rate at low temperature as an indicator; it was found that the seedling mortality rate was continuously distributed in the population, that is, cold tolerance is a quantitative trait controlled by multiple genes; further, the major effect QTL was found on chromosome 8 in rice (Rao et al. 2013).

Wang et al. (2009c) investigated a set of RILs using the germination rate under low-temperature stress as an indicator and detected seven QTLs for cold tolerance on chromosomes 4, 6, and 9 in rice. The majority of known QTLs for cold tolerance are mainly located on chromosomes 4 and 8, accounting for 16.22 and $13.51 \%$ of the total QTLs, respectively (Rao et al. 2013). At present, few studies have attempted to enhance cold tolerance of rice by molecular breeding. This is probably because cold tolerance in rice is a cumulative trait regulated by multiple genes, and single-gene transformation techniques have limited efficiency in improving rice cold tolerance.

Salt damage is one of the important causes for decline in rice yield and saline-alkali soil covers an area of approximately 100 million $\mathrm{hm}^{2}$ in China (Hu et al. 2010). To date, a few genes for salt tolerance have been cloned (Table 4) and breeding practices for salt resistance have been carried out using GEB. In 2006, the salt tolerance gene OPBPI was transferred into rice using a gene gun method and the obtained transgenic plants showed faster growth with significantly higher chlorophyll content and biomass yield than the non-transgenic control ( $\mathrm{Li}$ and Guo 2006). The rice $H A L 2$-like gene $(R H L)$ was transferred into the japonica variety Hejiang 19 using an Agrobacteriummediated method, and the screened positive plants showed improved salt tolerance at the seedling stage with less damage to cell membrane, strong vitality of leaf tissues, and enhanced salt tolerance under salt stress at the booting stage (Hu et al. 2010). The 2-pyrrol 5-carboxylate synthase (P5CS) gene from leguminous plants was transferred into rice using the gene gun method and the transgenic plants obtained increased content of proline with enhanced salt tolerance in transgenic cells (Zhi et al. 2005). In addition, transgenic rice plants with enhanced salt tolerance were obtained by transferring single genes such as 1-phosphate mannitol dehydrogenase ( $m t l D)$ gene and 6-phosphate, sorbitol dehydrogenase ( $g u t D)$ gene, or double genes such as choline monooxygenase (CMO) gene/betaine aldehyde dehydrogenase $(B A D H)$ gene into rice varieties (Hu et al. 2010).

In 2006, Guo et al. (2006) transferred five salt tolerancerelated genes, $C M O, B A D H, 1$-phosphate mannitol dehydrogenase $(m t l D)$ gene, gutD, and S-adenosylmethionine decarboxylase $(S A M D C)$ gene, into the conventional japonica varieties Xiushui 11 and Zhonghua 11, indica varieties Teqing and hybrid restorer line Minghui 63 using Agrobacterium-mediated and gene gun methods; the five salt tolerance genes were then pyramided through conventional cross breeding and the rice line Xiushui 11 with nine genotypes was bred; further, these rice lines were chosen for comprehensive evaluation and effective utilization in south Zhejiang Province. Using map-based cloning, Ren et al. (2005) isolated the gene SKCl that is involved in regulating $\mathrm{K}(+) / \mathrm{Na}(+)$ homeostasis under salt stress, providing a potential tool for improving salt tolerance in crops.

In China, few studies have investigated submergence stress in rice. New submergence-tolerant germplasm such as 94D-05, 94D-34, and 94D-54D have been obtained using an exogenous DNA introduction method, and the 
varieties Guizhao 2, Hui 41, 8105/D100, and Shanyou 63 with strong submergence tolerance were screened out under artificial simulation conditions ( $\mathrm{Li}$ and $\mathrm{Li} 2000$ ).

\section{Molecular breeding for rice grain quality}

Rice quality, as jointly determined by the appearance, processing, cooking, eating, and nutrition of rice, is the characteristic of rice commercialization and industrialization. In China, many genes and QTLs related to rice quality have been cloned (Table 4), and some genes are used in practices of breeding.

Using MAS with the functional marker GRM04, new hybrid rice materials with strong fragrance were bred in Guangdong Academy of Agricultural Sciences by introducing fragrant $(f g r)$ gene into the three-line maintainer lines Tianfeng B, Rongfeng B, Taifeng B, and Zhenfeng B as well as the elite restorer lines Guanghui 998, Guanghui 290, and Guanghui 372. New wx-containing rice lines with low content of amylose were developed (1.36\% in D154, $14.28 \%$ in D156, and $13.13 \%$ in D174 vs. $26.8 \%$ in Tianfeng B).

Hybrid combinations were configured for pyramid breeding using Wuyunjing 7 as female parent and the Stv$b i$ - and $W x-m q$-carrying Guandong 194 as male parent; the marker SCAR co-segregated with Stv-bi and the functional marker CAPS linked to $W x-m q$ were used to detect the target loci in segregating generations; Stv-bi and $W x-m q$ were simultaneously transferred into high-yielding rice varieties, and a new rice line (Ning 9108) with improved quality, disease resistance, yield, and agronomic traits was screened out and bred by a combination of field breeding, resistance identification, and grain endosperm appearance identification (Yao et al. 2010). Wang et al. (2009a) firstly designed InDel markers in the coding region of $A L K$ and $f g r$, which controlled gelatinization temperature (GT) and dominated the trait of rice fragrance; these two genes were successfully introgressed in Minghui 63 lines according to the progress of backcross pyramiding using the two developed molecular markers; the improved Minghui 63 lines exhibited significant low GT and high gel consistency (GC), while the white core chalkiness decreased and fragrant trait expressed in these lines; the results elucidated that the quality of Minghui63 has been improved significantly in terms of rice appearance, cooking, and eating quality.

\section{Molecular breeding for improved physiological traits}

High-photosynthetic efficiency is one of the most physiological traits for enhancing rice biomass and grain yield potential. In China, a number of rice genes related to physiological traits have been cloned (Table 4). These genes have been used in molecular breeding of rice for high-photosynthetic efficiency as a new means of physiological breeding, relative to rice breeding of plant architecture in the 1960s. The focus of rice breeding for highphotosynthetic efficiency is to explore potential of the single-leaf photosynthetic rate.

C4 plants are considered to have higher photosynthetic efficiency than C3 plants by lower photorespiratory consumption. Phosphoenolpyruvate carboxylase (PEPCase) is the key enzyme for $\mathrm{CO}_{2}$ fixation in $\mathrm{C} 4$ plants. A maize $P E P C$ gene was transformed into rice variety to produce new transgenic rice materials. Scholars have investigated the possible mechanisms of unique $\mathrm{CO}_{2}$ assimilation and high-photosynthetic efficiency in the rice variety carrying PEPC; high-yielding rice plants with stable high-photosynthetic efficiency were obtained by system selection and multi-generation cultivation; finally, high-yielding rice varieties with high-photosynthetic efficiency were bred (He et al. 2005). The attempts of rice breeding for high-photosynthetic efficiency by a combination of conventional breeding and molecular biotechnology provide new approaches for breeding super rice in the future.

Physiological analysis demonstrated that PEPCase activity of Kitaake-PEPC transgenic rice varied in the tillering and heading stages, as well as different growth stages of flag leaf, all significantly higher than that in the parent Kitaake (He et al. 2005). Ding et al. (2007b) studied the photosynthetic characteristics of sorghum C4-type PEPC transgenic rice and found that $\mathrm{CO}_{2}$ compensation point and photorespiration rate significantly decreased while light-saturated photosynthetic rate and carboxylation rate increased in transgenic plants, reflecting the photosynthetic characteristics of C4 plants. Wang et al. (2004a) also indicated that the major economic traits of $P E P C$ transgenic rice, including effective panicles per plant, total grains per panicle, thousand-grain weight, and yield per plant, were respectively improved by $14.9,5.7,1.3$, and $13.9 \%$ compared to those of the original parent Kitaake.

Regarding the same traits of PEPC $+P P D K$ transgenic rice, the effective panicles and yield per plant were, respectively, improved by 29.1 and $27.0 \%$ compared to the receptor parent Kitaake (He et al. 2005). In $\mathrm{BC}_{1} \mathrm{~F}_{1}$, $\mathrm{BC}_{2} \mathrm{~F}_{1}$, and $\mathrm{BC}_{1} \mathrm{~F}_{2}$ of $P E P C$-containing Shuhui 881 , the numbers of tillers, effective tillers, thousand-grain weight, and regenerated shoots all increased compared to those of the control variety Shuhui 881 . The above studies have laid a foundation for molecular breeding of high-photosynthetic efficiency in super rice. In addition, researchers from the National Hybrid Rice Engineering Technology Research Center (Changsha City, Hunan Province) have mapped multiple high-yield, high-photosynthetic efficiency genes 
(Table 4), identified dozens of functional molecular markers and candidate genes, and created a large amount of germplasms with high-photosynthetic efficiency and the genes of key photosynthetic enzyme in C4 plants.

In China, rice heterosis is mainly utilized by cultivating male sterile line, male sterile maintainer line, and male sterile restorer line (collectively referred to as three-line), so as to select dominant combinations (Sun et al. 2012). In recent years, restorer genes and wide compatibility genes have been successively cloned along with rapid development of biotechnology (Table 4), and the heterosis in indica and japonica subspecies has been gradually shifted from exploratory research to practical application.

The wide compatibility gene $S 5$ of rice was cloned in 2008 (Yang et al. 2012) and rapidly used in production practices thereafter. By designing molecular markers of $S 5$, Yang et al. (2009a) have screened out two restorer lines and a large amount of new rice germplasms carrying the wide compatibility gene $S 5-n$. The functional markers of $S 5-n$ were useful to identify rice resources and detect hybrid purity (Zhang et al. 2010a).

\section{Prospects}

In recent years, great progress has been made on molecular breeding in rice and the per unit area yield of this crop has been significantly improved in China. What then is the best path to increasing grain yield and further improve the quality of rice?

First is to pay more attention to the development and utilization of wild rice. Narrow genetic background of parent materials is the main cause for the undesirable crop yield, quality, and resistance, while wild rice provides rich genetic resources with good traits such as strong pest resistance and stress tolerance. Second is to understand the vital role of wide compatibility resources in rice heterosis. Wide compatibility rice materials have been continuously discovered and applied to hybrid rice breeding. Wide compatible genes can overcome the hybrid obstacles in subspecies and play an important role in the utilization of indica-japonica heterosis.

Likewise, it is urgent to find out intermediate resources with different degrees of compatibility between the cultivated and wild rice, which will overcome the incompatibility between cultivated and wild rice. In this way, high-quality resources of wild rice can be continuously integrated into cultivated rice.

Furthermore, it is recommended combining transgenic technology and MAS for MDB. The so-called MDB in crop is a novel breeding method with bioinformatics as the platform and genomic and proteomic databases as the basis, which integrates valuable information on crop genetics, physiology and biochemistry, and biological statistics in the crop breeding process. According to the breeding objectives and growth environment of specific crop, MDB designs the optimal scheme and then carries out trials of crop breeding.

MDB mainly involves three steps (Xu and Zhu 2012): (1) to map QTLs for all relevant agronomic traits; (2) to evaluate allelic variation in these QTLs; and (3) to carry out design breeding (Fig. 1). MDB generally has the following requirements: (a) high-density molecular genetic map and high-efficiency molecular marker techniques; (b) sufficient understanding of important genes (QTLs) regarding the location and function; (c) a complete genetic information database established for MDB; (d) a collection of germplasm and intermediate materials applicable for design breeding, including important core germplasm or the backbone parents and their derived RILs with target traits, near-isogenic lines, DH population, chromosome fragment introgression/substitution lines; and (e) improved statistical analysis method and relevant software developed for simulation studies on directed creation of new crop varieties. The above conditions have been met in the case of rice.

The development of rice breeding from conventional genetics to molecular design of new varieties is a general trend, which ensures the breeding of new varieties with improved agronomic traits in terms of the yield, grain quality, select efficiency, disease and pest resistance, and stress tolerance, further contributing to the protection of national food and environmental security.

Open Access This article is distributed under the terms of the Creative Commons Attribution License which permits any use, distribution, and reproduction in any medium, provided the original author(s) and the source are credited.

\section{References}

Ashikari M, Sakakibara H, Lin S, Yamamoto T, Takashi T, Nishimura A, Angeles ER, Qian Q, Kitano H, Matsuoka M (2005) Cytokinin oxidase regulates rice grain production. Science 309:741-745

Cao L, Zhan X, Zhuang J, Cheng S (2005) Breeding of Indica hybrid rice Guodao 1 with good quality, high yield and resistance to bacterial leaf blight by marker-assisted selection technique. Hybrid Rice 20:16-18

Cao L, He L, Zhan X, Zhuang J, Cheng S (2006) Guodao 3, a new hybrid rice combination with good quality, high yield and disease resistance. Hybrid Rice 21:83-84

Chen J, Wang L, Pang X, Pan Q (2006) Genetic analysis and fine mapping of a rice brown planthopper (Nilaparvata lugens Stal) resistance gene bph19(t). Mol Genet Genomics 275:321-329

Chen R, Zhao X, Shao Z, Wei Z, Wang Y, Zhu L, Zhao J, Sun M, He $\mathrm{R}$, He G (2007) Rice UDP-glucose pyrophosphorylase1 is essential for pollen callose deposition and its co-suppression results in a new type of thermosensitive genetic male sterility. Plant Cell 19:847-861 
Chen S, Yang Y, Shi W, Ji Q, He F, Zhang Z, Cheng Z, Liu X, Xu M (2008) Badh2, encoding betaine aldehyde dehydrogenase, inhibits the biosynthesis of 2-Acetyl-1-Pyrroline, a major component in rice fragrance. Plant Cell 20:1850-1861

Chen S, Ni D, Lu X, Li L, Wang W, Zhang Q, Zhao K, Zhang L, Guo $\mathrm{X}$, Yang J (2009) Pyramiding Xa23, Pi9 and Bt genes by molecular marker-assisted selection. Journal Biol 26:7-9

Chen J, Shi Y, Liu W, Chai R, Fu Y, Zhuang J, Wu J (2011a) A Pid3 allele from rice cultivar Gumei2 confers resistance to Magnaporthe oryzae. J Genet Genomics 38:209-216

Chen S, Liu X, Zeng L, Ouyang D, Yang J, Zhu X (2011b) Genetic analysis and molecular mapping of a novel recessive gene $x a 34(t)$ for resistance against Xanthomonas oryzae pv. oryzae. Theor Appl Genet 122:1331-1338

Chen Y, Fan X, Song W, Zhang Y, Xu G (2012) Over-expression of OsPIN2 leads to increased tiller numbers, angle and shorter plant height through suppression of OsLAZY1. Plant Biotechnol J 10:139-149

Cheng S, Hu P (2008) Development strategy of rice science and technology in china. Chin J Rice Sci 22:223-226

Cheng Z, Liu C, Yang D, Lu L, Ye L, Zheng X, Ye X (2011) Molecular markers-assisted selection of restorer line of dense and erect panicle. Mol Plant Breed 9:561-566

Deng Q, Zhou Y, Jiang Z, Wan Y, Zhao B, Yang L, Li P (2005) Pyramiding bacterial blight $(\mathrm{BB})$ resistance genes (Xa21, Xa4 and $\mathrm{Xa23}$ ) into rice and its effect analysis. Acta Agronomica Sinica 131:1241-1246

Ding Y, Wang X, Su L, Zhai J, Cao S, Zhang D, Liu C, Bi Y, Qian Q, Cheng Z, Chu C, Cao X (2007a) SDG714, a Histone H3K9 methyltransferase, is involved in Tos17 DNA methylation and transposition in rice. Plant Cell 19:9-22

Ding Z, Zhao M, Jing Y, Li L, Kuang T (2007b) Effect of overexpression of maize $P P C$ gene on photosynthesis in transgenic rice plants. Acta Agronomica Sinica 33:717-722

Duan Y, Diao Z, Liu H, Cai M, Wang F, Lan T, Wu W (2010) Molecular cloning and functional characterization of $O s J A G$ gene based on a complete-deletion mutant in rice (Oryza sativa L.). Plant Mol Biol 74:605-615

Fu F, Xue H (2010) Co-expression analysis identifies rice starch regulator 1, a rice AP2/EREBP family transcription factor, as a novel rice starch biosynthesis regulator. Plant Physiol 154:927-938

Gan Q, Bai H, Zhao X, Tao Y, Zeng H, Han Y, Song W, Zhu L, Liu G (2011) Transcriptional characteristics of Xa21-mediated defense responses in rice. J Integr Plant Biol 53:300-311

Gao Z, Zeng D, Cui X, Zhou Y, Yan M, Huang D, Li J, Qian Q (2003) Map-based cloning of the $A L K$ gene, which controls the gelatinization temperature of rice. Sci China C Life Sci 46:661-668

Ge L, Chao D, Shi M, Zhu M, Gao JP, Lin H (2008) Over-expression of the trehalose-6-phosphate phosphatase gene OSTPP1 confers stress tolerance in rice and results in the activation of stress responsive genes. Planta 228:191-201

Guan H, Chen Z, Wang Z, Mao D, Lin L, Pan R, Wu W, Zhou Y (2009) Molecule breeding of Jinkang $1 \mathrm{~A}$, male sterile line of rice with good quality and blast resistance. J Fujian Agric For Univ 38:450-455

Guo L, Xue D, Wang H, Chen S, Lu D, Zeng D, Gao Z, Yan M, Huang D, Qian Q (2006) Improvement of rice salt-tolerance by using an integrated method of gene transformation and traditional breeding. Chin J Rice Sci 20:141-146

Han Y, Cao H, Jiang J, Xu Y, Du J, Wang X, Yuan M, Wang Z, Xu Z, Chong K (2008) Rice root architecture associated 1 binds the proteasome subunit RPT4 and is degraded in a D-Box and proteasome-dependent manner. Plant Physiol 148:843-855

He G, Sun C, Fu Y, Fu Q, Zhao K, Wang C, Zhang Q, Ling Z, Wang $X$ (2004) Pyramiding of senescence-inhibition IPT gene and $\mathrm{Xa} 23$ for resistance to bacterial blight in rice (Oryza sativa L.). Acta Genetica Sinica 31:836-841
He L, Li P, Xiang X, Li J, Zhang K (2005) Some photosynthetic characteristics in transgenic rice with maize phosphoenolpyruvate carboxylase gene (PEPC). Plant Physiol Commun 41:461-463

Hiroaki T, Zhang Y, Susumu H, Minami O, Sae SS, Tetsuo O, Qian Q, Nishimura M, Kitano H, Xie H, Fang XH, Yoshida H, Kyozuka J, Chen F, Sato Y (2011) LAX PANICLE2 of rice encodes a novel nuclear protein and regulates the formation of axillary meristems. Plant Cell 23:3276-3287

Hou X, Xie K, Yao J, Qi Z, Xiong L (2009) A homolog of human ski-interacting protein in rice positively regulates cell viability and stress tolerance. Proc Natl Acad of Sci 106:6410-6415

Hu H, You J, Fang Y, Zhu X, Qi Z, Xiong L (2008) Characterization of transcription factor gene SNAC2 conferring cold and salt tolerance in rice. Plant Mol Biol 67:169-181

Hu S, Tao H, Qian Q, Guo L (2010) Progresses on genetics and molecular breeding for salt-tolerance in rice. Mol Plant Breed 8:629-640

Hu B, Zhu C, Li F, Tang J, Wang Y, Lin A, Liu LC, Che R, Chu C (2011) LEAF TIP NECROSIS1 plays a pivotal role in the regulation of multiple phosphate starvation responses in rice. Plant Physiol 156:1101-1115

Hu J, Wang K, Huang W, Liu G, Gao Y, Wang J, Huang Q, Ji Y, Qin X, Wan L, Zhu R, Li S, Yang D, Zhu Y (2012) The rice pentatricopeptide repeat protein RF5 restores fertility in honglian cytoplasmic male-sterile lines via a complex with the glycinerich protein GRP162. Plant Cell 24:109-122

Hua L, Wu J, Chen C, Wu W, He X, Lin F, Wang L, Ashikawa I, Matsumoto T, Wang L, Pan Q (2012) The isolation of Pil, an allele at the Pik locus which confers broad spectrum resistance to rice blast. Theor Appl Genet 125:1047-1055

Huang Y, Xiao B, Xiong L (2007) Characterization of a stress responsive proteinase inhibitor gene with positive effect in improving drought resistance in rice. Planta 226:73-85

Huang X, Qian Q, Liu Z, Sun H, He S, Luo D, Xia G, Chu C, Li J, Fu $X$ (2009) Natural variation at the DEPl locus enhances grain yield in rice. Nat Genet 41:494-497

Huang J, Tang D, Shen Y, Qin B, Hong L, You A, Li M, Wang X, Yu $\mathrm{H}$, Gu M, Cheng Z (2010) Activation of gibberellin 2-oxidase 6 decreases active gibberellin levels and creates a dominant semidwarf phenotype in rice (Oryza sativa L.). J Genet Genomics 37:23-36

Ji Q, Zhang M, Lu J, Wang H, Lin B, Liu Q, Chao Q, Zhang Y, Liu C, $\mathrm{Gu} \mathrm{M}$, Xu M (2012) Molecular basis underlying the S5dependent reproductive isolation and compatibility of Indica/ Japonica rice hybrids. Plant Physiol 158:1319-1328

Jia H, Ren H, Gu M, Zhao J, Sun S, Chen J, Wu P, Xu G (2011) The phosphate transporter gene OsPht18 is involved in phosphate homeostasis in rice. Plant Physiol 156:1164-1175

Jiang J, Tan L, Zhu Z, Fu Y, Liu F, Cai H, Sun C (2012) Molecular evolution of the TACl gene from rice (Oryza sativa L.). J Genet Genomics 39:551-560

Jiao Y, Wang Y, Xue D, Wang J, Yan M, Liu G, Dong G, Zeng D, Lu Z, Zhu X, Qian Q, Li J (2010) Regulation of OsSPL14 by OsmiR156 defines ideal plant architecture in rice. Nat Genet 42:541-544

Jin S, Liu W, Zhu X, Wang F, Li J, Liu Z, Liao Y, Zhu M, Huang H, Liu Y (2007) Improving blast resistance of a thermo-sensitive genic male sterile line GD-8S by molecular marker- assisted selection. Chin J Rice Sci 21:599-604

Jin J, Huang W, Gao J, Yang J, Shi M, Zhu M, Luo D, Lin H (2008) Genetic control of rice plant architecture under domestication. Nat Genet 40:1365-1369

Kovi MR, Zhang Y, Yu S, Yang G, Yan W, Xing Y (2011) Candidacy of a chitin-inducible gibberellin-responsive gene for a major 
locus affecting plant height in rice that is closely linked to green revolution gene $s d 1$. Theor Appl Genet 123:705-714

Li N, Guo Z (2006) Overexpression of two different transcription factors, $O P B P 1$ and $O s i W R K Y$, enhances resistance against pathogen attack and salt stress in rice. Chin J Rice Sci 20:13-18

Li Y, Li S (2000) Effect of submergence on physiological indexes and yield component at reproductive stage in rice. J Wuhan Bot Res $18: 117-122$

Li X, Qian Q, Fu Z, Wang Y, Xiong G, Zeng D, Wang X, Liu X, Teng S, Hiroshi F, Yuan M, Luo D, Han B, Li J (2003) Control of tillering in rice. Nature 422:618-621

Li P, Wang Y, Qian Q, Fu Z, Wang M, Zeng D, Li B, Wang X, Li J (2007) LAZY1 controls rice shoot gravitropism through regulating polar auxin transport. Cell Res 17:402-410

Li H, Xue D, Gao Z, Yan M, Xu W, Xing Z, Huang D, Qian Q, Xue Y (2009a) A putative lipase gene EXTRA GLUME1 regulates both empty-glume fate and spikelet development in rice. Plant $\mathrm{J}$ 57:593-605

Li S, Qian Q, Fu Z, Zeng D, Meng X, Kyozuka J, Maekawa M, Zhu X, Zhang J, Li J, Wang Y (2009b) Short panicle1 encodes a putative PTR family transporter and determines rice panicle size. Plant J 58:592-605

Li F, Liu W, Tang J, Chen J, Tong H, Hu B, Li C, Fang J, Chen M, Chu C (2010a) Rice DENSE AND ERECT PANICLE 2 is essential for determining panicle outgrowth and elongation. Cell Res 20:838-849

Li H, Pinot F, Sauveplane V, Danièle WR, Diehl P, Schreiber L, Franke R, Zhang P, Chen L, Gao YW, Liang W, Zhang D (2010b) Cytochrome P450 family member CYP704B2 catalyzes the $\omega$ hydroxylation of fatty acids and is required for anther cutin biosynthesis and pollen exine formation in rice. Plant Cell 22:173-190

Li H, Yuan Z, Gema VB, Yang C, Liang W, Zong J, Wilson ZA, Zhang D (2011a) PERSISTENT TAPETAL CELL1 Encodes a PHD-Finger protein that is required for tapetal cell death and pollen development in rice. Plant Physiol 156:615-630

Li Y, Fan C, Xing Y, Jiang Y, Luo L, Sun L, Shao D, Xu C, Li X, Xiao J, He Y, Zhang Q (2011b) Natural variation in GS5 plays an important role in regulating grain size and yield in rice. Nat Genet 43:1266-1269

Li C, Wei J, Lin Y, Chen H (2012a) Gene silencing using the recessive rice bacterial blight resistance gene $x a 13$ as a new paradigm in plant breeding. Plant Cell Rep 31:851-862

Li J, Chu H, Zhang Y, Mou T, Wu C, Zhang Q, Xu J (2012b) The rice $H G W$ gene encodes a ubiquitin-associated (UBA) domain protein that regulates heading date and grain weight. PLoS One 7:e34231

Li S, Zhao B, Yuan D, Duan M, Qian Q, Tang L, Wang B, Liu X, Zhang J, Wang J, Sun J, Liu Z, Feng Y, Yuan L, Li C (2013) Rice zinc finger protein DST enhances grain production through controlling Gnla/OsCKX2 expression. Proc Natl Acad of Sci 110:3167-3172

Liang K, Wang N, Yang R (1992) Inheritance and breeding utilization of panicle exsertion of rice. J Fujian Agric Coll 21:380-385

Lin Z, Griffith ME, Li X, Zhu Z, Tan L, Fu Y, Zhang W, Wang X, Xie $D$, Sun C (2007) Origin of seed shattering in rice (Oryza sativa L.). Planta 226:11-20

Liu $\mathrm{H}, \mathrm{Xu} \mathrm{Y}, \mathrm{Xu} \mathrm{Z}$, Chong $\mathrm{K}$ (2007a) A rice YABBY gene, $O s Y A B B Y 4$, preferentially expresses in developing vascular tissue. Dev Genes Evol 217:629-663

Liu K, Wang L, Xu Y, Chen N, Ma Q, Li F, Chong K (2007b) Over expression of OSCOIN, a putative cold inducible zinc finger protein, increased tolerance to chilling, salt and drought, and enhanced proline level in rice. Planta 226:1007-1016

Liu N, Jiang L, Zhang W, Liu L, Zhai H, Wan J (2008a) Role of embryo LOX3 Gene under adversity stress in rice (Oryza sativa L.). Chin J Rice Sci 22:8-14
Liu W, Wang F, Jin S, Zhu X, Li J, Liu Z, Liao Y, Zhu M, Huang H, Fu F, Liu Y (2008b) Improvement of rice blast resistance in TGMS line by pyramiding of $\mathrm{Pil}$ and $\mathrm{Pi2}$ through molecular markerassisted selection. Acta Agronomica Sinica 34:1128-1136

Liu W, Wu C, Fu Y, Hu G, Si H, Zhu L, Luan W, He Z, Sun Z (2009) Identification and characterization of HTD2: a novel gene negatively regulating tiller bud outgrowth in rice. Planta 230:649-658

Liu Z, Zhao J, Li Y, Zhang W, Jian G, Peng Y, Qi F (2012) Nonuniform distribution pattern for differentially expressed genes of transgenic rice huahui 1 at different developmental stages and environments. PLoS One 7:e37078

Long Y, Zhao L, Niu B, Su J, Wu H, Chen Y, Zhang Q, Guo G, Zhuang C, Mei M, Xia J, Wang L, Wu H, Liu Y (2008) Hybrid male sterility in rice controlled by interaction between divergent alleles of two adjacent genes. Proc Natl Acad Sci USA 105:18871-188765

Luan W, Liu Y, Zhang F, Song Y, Wang Z, Peng Y, Sun Z (2011) OsCD1 encodes a putative member of the cellulose synthase-like D sub-family and is essential for rice plant architecture and growth. Plant Biotechnol 9:513-524

Luo D, Xu H, Liu Z, Guo J, Li H, Chen L, Fang C, Zhang Q, Bai M, Yao N, Wu H, Ji C, Zheng H, Chen Y, Ye S, Li X, Zhao X, Li R, Liu Y (2013) A detrimental mitochondrial-nuclear interaction causes cytoplasmic male sterility in rice. Nat Genet 45:573-577

Miah M, Rafii MY, Ismail MR, Puteh AB, Rahim HA, Asfaliza R, Latif MA (2013) Blast resistance in rice: a review of conventional breeding to molecular approaches. Mol Biol Rep 40:2369-2388

Mu P, Li Z, Li C, Zhang H, Wu C, Li C, Wang X (2003) QTL detection and drought-resistant analysis of root traits between upland rice and traditional rice. Chin Sci Bull 48:2162-2169

Pei Q, Wang C, Liu P, Wang J, Zhao K (2011) Marker-assisted selection for pyramiding disease and insect resistance genes in rice. Chin J Rice Sci 25:119-129

Peng X, Wang K, Hu C, Zhu Y, Wang T, Yang J, Tong J, Li SQ, Zhu Y (2010) The mitochondrial gene orfH79 plays a critical role in impairing both male gametophyte development and root growth in CMS-Honglian rice. BMC Plant Biol 10:125

Porter BW, Chittoor JM, Yano M, Sasaki T, White FF (2003) Development and mapping of markers 1 inked to the rice bacterial blight resistance gene Xa7. Crop Sci 43:1484-1492

Qiao Y, Piao R, Shi J, Lee S, Jiang W, Kim BK, Lee J, Han L, Ma W, Koh HJ (2011) Fine mapping and candidate gene analysis of dense and erect panicle 3, DEP3, which confers high grain yield in rice (Oryza sativa L.). Theor Appl Genet 122:1439-1449

Qiu Y, Guo J, Jing S, Zhu L, He G (2010) High-resolution mapping of the brown planthopper resistance gene Bph6 in rice and characterizing its resistance in the 9311 and Nipponbare near isogenic backgrounds. Theor Appl Genet 121:1601-1611

Qu Y, Mu P, Li X, Tian Y, Wen F, Zhang H, Li Z (2008) QTL mapping and correlations between leaf water potential and drought resistance in rice under upland and lowland environments. Acta Agronomica Sinica 34:198-206

Rao Y, Yang Y, Huang L, Pan J, Ma B, Qian Q, Zeng D (2013) Research progress on cold stress in rice. Mol Plant Breed 11:443-450

Ren Z, Gao J, Li L, Cai X, Huang W, Chao D, Zhu M, Wang Z, Luan S, Lin $\mathrm{H}$ (2005) A rice quantitative trait locus for salt tolerance encodes a sodium transpoter. Nat Genet 37:1141-1146

Ruan H, Yan C, An D, Liu R, Chen J (2008) Identifying and mapping new gene $X a 32(T)$ for resistance to bacterial blight from Oryza meyeriana L. Acta Agriculture Boreali-occidentalis Sinica 17:170-174

Shi Z, Wang J, Wan X, Shen G, Wang X, Zhang J (2007) Overexpression of rice $O s A G O 7$ gene induces upward curling of the leaf blade that enhanced erect-leaf habit. Planta 226:99-108 
Song X, Huang W, Shi M, Zhu M, Lin H (2007) A QTL for rice grain width and weight encodes a previously unknown RING-type E3 ubiquitin ligase. Nat Genet 39:623-630

Su Y, Rao Y, Hu S, Yang Y, Gao Z, Zhang G, Liu J, Hu J, Yan M, Dong G, Zhu L, Guo L, Qian Q, Zeng D (2011) Map-based cloning proves $q G C-6$, a major QTL for gel consistency of Japonica/Indica cross, responds by Waxy in rice (Oryza sativa L.). Theor Appl Genet 123:859-867

Sun S, Chao D, Li X, Shi M, Gao J, Zhu M, Yang H, Luan S, Lin H (2009) OsHAL3 mediates a new pathway in the light-regulated growth of rice. Nat Cell Biol 11:845-851

Sun J, Liu D, Wang J, Ma D, Tang L, Gao H, Xu Z, Chen WF (2012) The contribution of intersubspecific hybridization to the breeding of super-high-yielding japonica rice in northeast China. Theor Appl Genet 125:1149-1157

Tan G, Ren X, Weng Q, Shi Z, Zhu L, He G (2004) Mapping of a new resistance gene to bacterial blight in rice line introgressed from Oryza officinalis. Acta Genetica Sinica 31:724-729

Tang J, Zhu X, Wang Y, Liu L, Xu B, Li F, Fang J, Chu C (2011) Semi-dominant mutations in the CC-NB-LRR-type $\mathrm{R}$ gene, $N L S 1$, lead to constitutive activation of defense responses in rice. Plant J 66:996-1007

Teng S, Qian Q, Zeng DL, Yasufumi K, Kan F, Huang D, Zhu L (2002) Analysis of gene loci and epistasis for drought tolerance in seedling stage of rice (Oryza sativa L.). Acta Genetica Sinica 29:235-240

Tong H, Liu L, Jin Y, Du L, Yin Y, Qian Q, Zhu L, Chu C (2012) DWARF AND LOW-TILLERING acts as a direct downstream target of a GSK3/SHAGGY-Like kinase to mediate brassinosteroid responses in rice. Plant Cell 24:2562-2577

Wang D, Wang S, Wu S, Li C, Jiao D, Luo Y, Wang X, Du S (2004a) Inheritance and expression of the maize $P E P C$ gene in progenies of transgenic rice bred by crossing. Acta Genetica Sinica 31:195-201

Wang Y, Li S, Han Y, Gao K (2004b) Breeding and utilization of restorer line Shuhui 527 with good grain quality and high combining ability in grain yield. Hybrid Rice 19:12-14

Wang Y, Xu H, Wei W, Chai C, Xiao Y, Zhang Y, Chen B, Xiao G, Ouwerkerk PB, Wang M, Zhu Z (2007) Molecular cloning and expression analysis of a monosaccharide transporter gene OsMST4 from rice (Oryza sativa L.). Plant Mol Biol 65:439-451

Wang Y, Xiao Y, Zhang Y, Chai C, Wei G, Wei X, Xu H, Wang M, Ouwerkerk PBF, Zhu Z (2008) Molecular cloning, functional characterization and expression analysis of a novel monosaccharide transporter gene OsMST6 from rice (Oryza sativa L.). Planta 228:525-535

Wang Y, Fu X, Gao G, He Y (2009a) Improving the grain quality of Minghui63, a restorer line of rice with good quality through marker-assisted selection. Mol Plant Breed 7:661-665

Wang Y, Zhu S, Liu S, Jiang L, Chen L, Ren Y, Han X, Liu F, Ji S, Liu X, Wan J (2009b) The vacuolar processing enzyme OsVPE1 is required for efficient glutelin processing in rice. Plant $\mathrm{J}$ 58:606-617

Wang Z, Wang J, Wang F, Bao Y, Wu Y, Zhang H (2009c) Genetic control of germination ability under cold stress in rice. Rice Sci $16: 173-180$

Wang E, Xu X, Zhang L, Zhang H, Lin L, Wang Q, Li Q, Ge S, Lu B, Wang W (2010a) Duplication and independent selection of cellwall invertase genes GIF1 and OSCIN1 during rice evolution and domestication. BMC Evol Biol 10:108

Wang Y, Ren Y, Liu X, Jiang L, Chen L, Han X, Jin M, Liu S, Liu F, Lv J, Zhou K, Su N, Bao Y, Wan J (2010b) OsRab5a regulates endomembrane organization and storage protein trafficking in rice endosperm cells. Plant J 64:812-824

Wang J, Yang J, Chen Z, Fan F, Zhu J, Yang J, Zhong W (2011) Pyramiding resistance gene $P i-t a, P i-b$, and $S t v-b i$ by marker- assisted selection in rice (Oryza sativa L.). Acta Agronomic Sinica 37:975-981

Wang C, Huang W, Ying Y, Li S, Secco D, Tyerman S, Whelan J, Shou H (2012a) Functional characterization of the rice SPXMFS family reveals a key role of OsSPX-MFS1 in controlling phosphate homeostasis in leaves. New Phytol 196:139-148

Wang S, Wu K, Yuan Q, Liu X, Liu Z, Lin X, Zeng R, Zhu H, Dong G, Qian Q, Zhang G, Fu X (2012b) Control of grain size, shape and quality by OSSPL16 in rice. Nat Genet 44:950-954

Wang J, Hu J, Qian Q, Xue H (2013) LC2 and OsVIL2 promote rice flowering by photoperiod-induced epigenetic silencing of $O s L F$. Mol Plant 6:514-527

Wei X, Xu J, Guo H, Jiang L, Chen S, Yu C, Zhou Z, Hu P, Zhai H, Wan J (2010) DTH8 suppresses flowering in rice, influencing plant height and yield potential simultaneously. Plant Physiol 153:1747-1758

Weng J, Gu S, Wan X, Gao H, Guo T, Su N, Lei C, Zhang X, Cheng Z, Guo X, Wang J, Jiang L, Zhai H, Wan J (2008) Isolation and initial characterization of $G W 5$, a major QTL associated with rice grain width and weight. Cell Res 18:1199-1209

Wu C, You C, Li C, Long T, Chen G, Byrne ME, Zhang Q (2008a) RID1, encoding a Cys2/His2-type zinc finger transcription factor, acts as a master switch from vegetative to floral development in rice. Proc Natl Acad Sci USA 105:12915-12920

Wu W, Cao L, Zhan X, Shen X, Chen S, Cheng S (2008b) The selection and breeding of hybrid rice Guodao 6 and its high yield cultural techniques. Food Crop 3:55-56

Wu W, Cao L, Zhan X, Shen X, Chen S, Cheng S (2008c) The selection and breeding of hybrid rice Ilyou-8006 and its cultivation techniques. Food Crop 4:77-78

Wu X, Li X, Xu C, Wang S (2008d) Fine genetic mapping of xa24, a recessive gene for resistance against Xanthomonas oryzae $p v$. oryzae in rice. Theor Appl Genet 118:185-191

Wu J, Zhuang W, Xiong Y, Yang Y, Deng H, Deng Q (2010a) Breeding of new hybrid rice combination Y Liangyou 7 with high yield and good quality by introducing yield-increase QTLs of wild rice. Hybrid Rice 25:20-22

Wu X, Fei Z, Zhang J, Wei L, Dong H, Zhou P (2010b) Breeding and Characteristic Analysis of a Photoperiod-sensitive Genetic Male Sterile Rice T16S with Pest-resistant $B t$ Gene. Hubei Agric Sci 49:2974-2977

Xiao H, Huang B, Zhang Y (2005) Application of PSM maker linked to gene Gm6 in rice resistant breeding. Guangdong Agric Sci $3: 50-53$

Xiao B, Huang Y, Tang N, Xiong L (2007) Over-expression of a LEA gene in rice improves drought resistance under the field conditions. Theor Appl Genet 115(1):35-46

Xiao H, Tang J, Yun F, Wang W, Li X, Jin L, Xie R, Luo H, Zhao X, Meng Z, He G, Zhu L (2009) STAMENLESS 1, encoding a single $\mathrm{C} 2 \mathrm{H} 2$ zinc finger protein, regulates floral organ identity in rice. Plant J 59:789-801

Xing Y, Zhang Q (2010) Genetic and molecular bases of rice yield. Annu Rev Plant Biol 61:421-442

Xu H, Zhu J (2012) Statistical approaches in QTL mapping and molecular breeding for complex traits. Chin Sci Bull 57:2637-2644

Xu J, Li J, Zheng X, Zou L, Zhu L (2001) QTL mapping of the root traits in rice. Acta Genetica Sinica 28:433-438

Xue W, Xing Y, Weng X, Zhao Y, Tang W, Wang L, Zhou H, Yu S, $\mathrm{Xu}$ C, Li X, Zhang Q (2008) Natural variation in Ghd7 is an important regulator of heading date and yield potential in rice. Nat Genet 40:761-767

Yang J, Wang J, Cao Q, Chen Z, Zhong W (2009a) Development and application of a functional marker for wide compatibility gene S5- $n$ of Rice. Acta Agronomica Sinica 35:2000-2007

Yang Q, Lin F, Wang L, Pan Q (2009b) Identification and mapping of Pi41, a major gene conferring resistance to rice blast in the 
Oryza sativa subsp indica reference cultivar, 93-11. Theor Appl Genet 118:1027-1034

Yang T, Zeng R, Zhu H, Chen L, Zhang Z, Ding X, Li W, Zhang G (2010) Effect of grain length gene $G S 3$ in pyramiding breeding of rice. Mol Plant Breed 8:59-66

Yang J, Zhao X, Cheng K, Du H, Ouyang YD, Chen J, Qiu S, Huang J, Jiang Y, Jiang L, Ding J, Wang J, Xu C, Li X, Zhang Q (2012) A killer-protector system regulates both hybrid sterility and segregation distortion in rice. Science 337:1336-1340

Yao S, Chen T, Zhang Y, Zhu Z, Zhao L, Zhao Q, Zhou L, Wang C (2010) Pyramiding of translucent endosperm mutant gene $W x$ $m q$ and rice stripe disease resistance gene $S t v-b^{i}$ by markerassisted selection in rice (Oryza sativa). Chin J Rice Sci 24:341-347

Yoshikawa T, Eiguchi M, Hibara KI, Ito JI, Nagato Y (2013) Rice SLENDER LEAF 1 gene encodes cellulose synthase-like D4 and is specifically expressed in M-phase cells to regulate cell proliferation. J Exp Bot 64:2049-2061

Yu Y, Tang T, Qian Q, Wang Y, Yan M, Zeng D, Han B, Wu C, Shi $\mathrm{S}$, Li J (2008) Independent losses of function in a polyphenol oxidase in rice: differentiation in grain discoloration between subspecies and the role of positive selection under domestication. Plant Cell 20:2946-2959

Yuan LP (1987) Strategic assumption of hybrid rice breeding. Hybrid Rice $1: 1-3$

Yuan B, Zhai C, Wang W, Zeng X, Xu X, Hu H, Lin F, Wang L, Pan $\mathrm{Q}$ (2011) The Pik-p resistance to Magnaporthe oryzae in rice is mediated by a pair of closely linked CC-NBS-LRR genes. Theor Appl Genet 122:1017-1028

Zhang Y, Zhu Y, Peng Y, Yan D, Li Q, Wang J, Wang L, He Z (2008) Gibberellin homeostasis and plant height control by EUI and a role for gibberellin in root gravity responses in rice. Cell Res $18: 412-421$
Zhang G, Xu Q, Zhu X, Qian Q, Xue H (2009) SHALLOT-LIKE1 Is a KANADI transcription factor that modulates rice leaf rolling by regulating leaf abaxial cell development. Plant Cell 21:719-735

Zhang A, Yang J, Xia S, Cao Q, Wang J, Tang S, Dai J, Chen Z, Zhong W (2010a) Germplasm screening and hybrid rice purity testing with functional marker of wide compatibility gene $\mathrm{S5}$ n. Jiangsu J Agric Sci 26:1133-1138

Zhang D, Liang W, Yin C, Zong J, Gu F, Zhang D (2010b) OsC6, encoding a lipid transfer protein, is required for postmeiotic anther development in rice. Plant Physiol 154:149-162

Zhang H, Xu C, He Y, Zong J, Yang X, Si H, Sun Z, Hu J, Liang W, Zhang D (2013a) Mutation in CSA creates a new photoperiodsensitive genic male sterile line applicable for hybrid rice seed production. Proc Natl Acad Sci USA 110:76-81

Zhang J, Zeng D, Zhu Y, Xie H, Cai Q, Lian L, Wu F, Luo X, Wang Y, Zheng T (2013b) Breeding of rice restore lines with whitebacked planthopper resistance by marker-assisted selection. Chin J Rice Sci 27:329-334

Zhao Y, Hu Y, Dai M, Huang L, Zhou D (2009) The WUSCHELrelated homeobox gene WOX11 is required to activate shootborne crown root development in rice. Plant Cell 21:736-748

Zhi L, Chen M, Yu T, Cao J, Zhu Y, Li Y (2005) The study of the transformation by $\mathrm{p} 5 \mathrm{cs}$ in rice cells. J Hubei Normal Univ 25:39-43

Zhu R, Huang W, Hu J, Liu W, Zhu Y (2013) Breeding and utilization of hybrid rice Lianyou 234 and NMS Line Bph68 $s$ resistance to brown planthopper. Nat Sci Educ 59:024-028

Zong G, Wang A, Wang L (2012) A pyramid breeding of eight grainyield related quantitative trait loci based on marker-assistant and phenotype selection in rice (oryza sativa L.). J Genet Genomics 39:335-350

Zou L, Sun X, Zhang Z, Liu P, Wu J, Tian C, Qiu J, Lu T (2011) Leaf rolling controlled by the homeodomain leucine zipper class IV gene Roc5 in rice. Plant Physiol 156:1589-1602 